\title{
Academic Integrity in Higher Education: Analysis of Research Publication and Web Citation
}

\section{Aziman Abdullah ${ }^{1}$ and Asar Abdul Karim²}

${ }^{1}$ Faculty of Computer Systems \& Software Engineering, Universiti Malaysia Pahang, Lebuhraya Tun Razak, 26300 Gambang, Pahang, Malaysia

${ }^{2}$ Centre for Modern Language \& Human Sciences, Universiti Malaysia Pahang, Lebuhraya Tun Razak, 26300 Gambang, Pahang, Malaysia

\section{Abstract}

Higher education is a critical organization for nation-building, either for economic development or social well-being. However, this noble and vital institution has been affected by the issue of "academic integrity" due to digital technology adoption, the Internet. Many research studies have been conducted and published, but the impact on the institution and society yet not been properly reported. This study attempts to

Corresponding Author:

Aziman Abdullah

aziman@ump.edu.my

Received: 5 August 2019

Accepted: 14 August 2019

Published: 18 August 2019

Publishing services provided by

Knowledge

(ㄷ) Aziman Abdullah and Asar

Abdul Karim. This article is

distributed under the terms of

the Creative Commons

Attribution License, which

permits unrestricted use and

redistribution provided that the

original author and source are credited.

Selection and Peer-review under the responsibility of the FGIC2019 Conference Committee. assess the impact of research on academic integrity by exploring its relationship with web citation. Quantitative method is adopted by analyzing data collected from Google Scholar, SCOPUS, and aHref web analytics cloud service. A strong positive correlation (Pearson's coefficient $=0.915$ ) of the published research works on "academic integrity" with web citation can be used as an effective strategy to put research into action in academic integrity. Thus, this study suggests that web citation is a potential metrics that can be used as an effective tool to measure the impact of research in academic integrity.

Keywords: academic integrity, higher education, web citation.

\section{Introduction}

In this $21^{s t}$ century, higher education has been challenged with rapid change and constant transformation that opens the door to new opportunities (Wang \& Wan Wart, 2007) as well as risks(Downes, 2017). The advancement of the Internet or digital technology has transformed higher education to become more accessible (Amigud, ArnedoMoreno, Daradoumis, \& Guerrero-Roldan, 2018) and affordable with online services (Hayes, Ruschman, \& Walker, 2009; Rajnish Kumar, Pritam Desale, 2013). This progress not only comes with the beneficial impact but also together with new opportunities, challenges and risks that significantly affect the future of higher education (Weller \& Anderson, 2013; Zorn, Haywood, \& Glachant, 2018). Many higher education institutions 
have addressed the needs to embrace the Industrial Revolution 4.0, which is about digital technology adoption with the right purpose and strategic. This digital technology is a disruptive may induce risks in higher education when the adoption been implemented without being mindful of the potential implications either in a good or bad. Higher education institution must resilience(Weller \& Anderson, 2013), ready with the new paradigm shift (Rogers, 2000; Taatila, 2017) that comes with digital technology. Higher education is one of the critical sectors not only for economic development but also in various aspects of national (Mathews \& Hu, 2007) and global sustainability development (Sibbel, 2009). The integrity that significantly defines a civilization (Walton, 2001) must be at the center and core values of the institution. In higher education, academic integrity is an issue that attracts many researchers to study about it. This issue is not only about student, academician and administrator, but affected external stakeholders like policy maker, government, parent, guardian and employer. In fact, issues regarding academic integrity or the case of academic corruption claimed to happen in all institutions in all countries, from the top person till the student (Tierney \& Sabharwal, 2017). This paper reviews the context of curriculum where related stakeholders in higher education are involved in academic integrity cases or potential being corrupt in the academic system. There are two objectives of this paper: first, to review the existing literature on academic integrity in higher education, and second, to assess the impact of research of academic integrity on the web. To this end, the paper addresses two research questions:

RQ1: What is the relationship between research publication with web citations in "academic integrity"?

RQ2: What is the impact of research publication on "academic integrity" in higher education in the form of research citation and web citation?

This study is important for higher education to address the issue of academic integrity affected by digital adoption (Housewright \& Schonfeld, 2008).

\section{Literature Review}

\subsection{Integrity Concepts}

There are various definitions of integrity, depending on the context of the discussion. The term complexity is challenging to be framed in a single and consistent theory due to different theories advance different aspects of the term (OECD, 2018). In etymology or source of the word, 'integrity' comes from the Latin word, integras, integer, meaning comprehensiveness, consistency, and purity(Sumi \& Mesner-Andolšek, 2016). In the 
area of computer science or digital technology, integrity means differently as compare to social science. Integrity in computer science is referred to as an assurance that information and programs are changed only in a specified and authorized manner (Council, 1991). It is one of the required criteria in the field of cyber security. While in social science, integrity can be viewed at least from eight perspectives (Huberts, 2018) which all of them are referring to a character or values held by individual, group, or organization. In this paper, however, the dominant one claimed by the literature which defines integrity as "professional exercises his tasks adequately, carefully and responsibly, taking into account all relevant interests." The definition in computer science and social science differs based on target actors which one for a machine and the later one is for human. Nevertheless, both are referring to a measurable quality value of trust.

\subsection{Academic Integrity}

In Islām, integrity places principally as a code of conduct which leads towards the establishment of human ethics. Once a Muslim tries the best to implement the three (3) Islamic aspects of Islāmic world-view which are tawhīd (Islāmic ideology), khilāfah (vicegerency) and 'adālah (justice); the person becomes an individual who abides Islāmic teachings in the daily life. $\mathrm{He} /$ she then will reach the highest point of a believer should be, i.e., to become the pious man (al-taqwā). Allāh mentions in the Qur'ān: "O mankind, We created you from male and female and made you into nations and tribes, that you may know one another. Verily, the most noble of you in the sight of Allāh, is the most righteous of you. Indeed, Allah is Knowing and Acquainted"-al-Qur'ān, 49: 13, adapted from('Alī, 1994). Building integrity in promoting human ethical foundation in this world life. One of the main elements of integrity is truthfulness. According to alGhazali, the truthfulness or sincerity has to appear in five aspects: in speech, intent/ will, determination, keeping promises, and action (Mohd Hasrul Shuhari et al., 2019). Integrity avoids the person to do such characteristics associated with those persons without integrity such as corruption, deception, and treachery. The Prophet says: "Truthfulness leads to al-birr (righteousness), and the righteousness leads to the Paradise; a man keeps on speaking the truth until he becomes a truthful person. Falsehood leads to al-fujūr (wickedness/ evil-doing), and the wickedness leads to the Hell/ Fire; a man may keep on telling lies till he is written before Allah, a liar" Șahịh al-Bukhārī, hạaīth no. 6094 (Al-Bukhārī, 1987), Sahịị Muslim, hadīth no: 2607 (Muslim, n.d.). In academic, issues associated with integrity like academic corruption (Tierney \& Sabharwal, 2017) or also known as academic fraud such as plagiarism (Maurer, Kappe, \& Zaka, 2006), 
academic dishonesty (Ercegovac \& Richardson, 2014) and cheating(McCabe, Treviño, \& Butterfield, 2001) are not new. For example, plagiarism had existed ever since more than a hundred year before (Quain, 1831). Academic integrity is not only about academic work by student or academician; it also covers administrative work in the academic system from the starting process of marketing, admission, graduation and till the end of program accreditation. A previous study (Altbach \& Vest, 2005) claimed due to high demand to access to higher education; there is much corruption in university or college admission process especially to the most prestigious universities. This over a decade claim become more significant today after recently Department of Justice in the United States uncovered a conspiracy on college entrance exams and admission to elite universities in the United States that linked with academic corruption (DoJ, 2019). Table 1 summarize the context of academic integrity happened in higher education.

TABLE 1: Academic Integrity in Higher Education Context.

Integrity Case
Cheating for admission (Sharma, 2015)
Bribery for admission (Liu \& Peng, 2015)
Plagiarism (Bouville, 2008)
Data fabrication in research (Nurunnabi \& Hossain,
2019)
Contract cheating (Amigud \& Lancaster, 2019)
Accreditation and licensing fraud (OECD, 2018)
Fake degrees/transcript (Grolleau, Lakhal, \& Mzoughi,
2016)

\begin{tabular}{|c|c|c|}
\hline \multicolumn{3}{|c|}{ Context } \\
\hline Before & During & After \\
\hline$x$ & & \\
\hline \multicolumn{3}{|l|}{$x$} \\
\hline & $x$ & \\
\hline & $x$ & \\
\hline & $x$ & \\
\hline & & $x$ \\
\hline & & $x$ \\
\hline
\end{tabular}

\section{Methodology}

This study adopts a quantitative analysis approach for the research methodology. The collected data are based on the contexts of research and action (see Table 2). The rationale of the Web database adopted in this study is because the Web platform can be used to represent the implementation of activities of the higher education on academic integrity. To restrict the searching, a single phrase "academic integrity" has been used as a search keyword from all the data source in both contexts. 
TABLE 2: Data Collection and Source.

\begin{tabular}{|c|c|c|c|}
\hline Context & Data source & Parameter & Searching Tools \\
\hline \multirow[t]{2}{*}{ Research } & SCOPUS & $\begin{array}{l}\text { Title, keywords, year, citation } \\
\text { counts }\end{array}$ & SCOPUS search \\
\hline & Google Scholars & $\begin{array}{l}\text { Title, keywords, year, citation } \\
\text { counts }\end{array}$ & $\begin{array}{l}\text { Harzing's Publish or Perish } \\
\text { version } 6\end{array}$ \\
\hline \multirow[t]{2}{*}{ Action } & Web search & $\begin{array}{l}\text { Keywords, number of search } \\
\text { interest score }\end{array}$ & Google Trends web service \\
\hline & Web pages & $\begin{array}{l}\text { Keyword, year, number of web } \\
\text { publication, web citation, *social } \\
\text { media sharing, web referral }\end{array}$ & aHref content explorer \\
\hline
\end{tabular}

\section{Results}

Table 3 shows the summary of data collection from the targeted sources with the phrase "academic integrity."

TABLE 3: Data Collection and Source.

\begin{tabular}{l|c|c|c|}
\hline Indexed database & Number of records & Year range & Date retrieved \\
\hline SCOPUS & 855 & $1983-2020$ & 28 May 2019 \\
\hline Google Scholars & 980 & $1880-2018$ & 28 May 2019 \\
\hline $\begin{array}{l}\text { Google trend } \\
\text { Ahref Content }\end{array}$ & 185 & $2004-2019$ & 28 May 2019 \\
\hline $\begin{array}{l}\text { Explorer } \\
\text { S }\end{array}$ & 5000 & $1979-2019$ & 28 May 2019 \\
\hline
\end{tabular}

Since the time of publications for research and web are not in the same duration for comparison, this study normalized the year range by scoping the year range from 2009 till 2019. Table 4 summarizes the number of publications associated with "academic integrity" within those years.

To investigate the relationship between publications and citation in "academic integrity," simple linear regression has been adopted in this study by measuring the Pearson's correlation coefficient of the targeted parameters. The details result of the analysis is shown in Appendix 1 and summarized in Table 5.

\section{Discussion}

There are two research questions to be discussed based on the findings.

1. RQ1: What is the relationship between research publications with web citations in "academic integrity"?

Based on Appendix 1, this study summarizes: - 
TABLE 4: Summary of Publication index and Citation on "Academic Integrity."

\begin{tabular}{|c|c|c|c|c|c|c|c|c|}
\hline \multirow[b]{2}{*}{ Year } & \multicolumn{4}{|c|}{ Publication index database } & \multicolumn{4}{|c|}{ Citation } \\
\hline & $\begin{array}{l}\text { Google } \\
\text { Scholar }\end{array}$ & SCOPUS & $\begin{array}{l}\text { Google } \\
\text { Search }\end{array}$ & aHref & $\begin{array}{l}\text { Google } \\
\text { Scholar }\end{array}$ & SCOPUS & $\begin{array}{c}\text { Web } \\
\text { Referral }\end{array}$ & $\begin{array}{l}\text { Social } \\
\text { Media }\end{array}$ \\
\hline 2009 & 68 & 35 & 530 & 23 & 3060 & 417 & 256 & 254 \\
\hline 2010 & 49 & 32 & 596 & 50 & 7133 & 347 & 630 & 14271 \\
\hline 2011 & 70 & 44 & 691 & 93 & 3186 & 235 & 878 & 11175 \\
\hline 2012 & 62 & 49 & 784 & 163 & 1506 & 422 & 1451 & 11149 \\
\hline 2013 & 64 & 51 & 718 & 247 & 2645 & 356 & 1904 & 26840 \\
\hline 2014 & 53 & 75 & 702 & 330 & 1176 & 429 & 2591 & 108317 \\
\hline 2015 & 48 & 48 & 688 & 377 & 927 & 148 & 2928 & 289935 \\
\hline 2016 & 43 & 124 & 739 & 490 & 715 & 269 & 3027 & 1331031 \\
\hline 2017 & 25 & 82 & 709 & 1022 & 662 & 154 & 6124 & 522500 \\
\hline 2018 & 10 & 95 & 751 & 1471 & 277 & 120 & 9194 & 709642 \\
\hline 2019 & 0 & 39 & 332 & 602 & 0 & 12 & 5649 & 155073 \\
\hline
\end{tabular}

TABLE 5: Significance Matrix based on P-value (alpha $=0.05)$.

\begin{tabular}{|c|c|c|c|c|c|c|c|c|c|}
\hline & \multirow[b]{2}{*}{ Source } & \multicolumn{4}{|c|}{ Publication } & \multicolumn{4}{|c|}{ Citation } \\
\hline & & $\begin{array}{l}\text { Google } \\
\text { Scholar }\end{array}$ & SCOPUS & $\begin{array}{l}\text { Google } \\
\text { Search }\end{array}$ & Web & $\begin{array}{l}\text { Google } \\
\text { Scholar }\end{array}$ & SCOPUS & $\begin{array}{c}\text { Web } \\
\text { Referral }\end{array}$ & $\begin{array}{l}\text { Social } \\
\text { Media }\end{array}$ \\
\hline \multirow{4}{*}{ 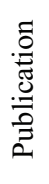 } & Google Scholar & & $\mathrm{X}$ & l & l & l & l & / & l \\
\hline & SCOPUS & & & 1 & / & l & l & / & / \\
\hline & Google Search & & & & $\mathrm{X}$ & $\mathrm{X}$ & l & l & I \\
\hline & aHref & & & & & $\mathrm{X}$ & $\mathrm{X}$ & l & I \\
\hline \multirow{4}{*}{ 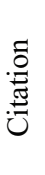 } & Google Scholar & & & & & & l & $\mathrm{X}$ & I \\
\hline & SCOPUS & & & & & & & 1 & / \\
\hline & Web Referral & & & & & & & & 1 \\
\hline & Social Media & & & & & & & & \\
\hline
\end{tabular}

Note: '/' is significant and ' $X$ ' is not significant

a. The relationship between Google Scholar indexing shows a negative, weak relationship with web referral and social media. Considering open access to Google Scholar data, this finding somehow indicates some errors in the conducted methodology. After comparing the data from the web search in Google Scholar, there are major differences between the data retrieved from the Web and the software tool Harzing's that used in this study. The reason for the difference is the limitation of data queries in the Harzing's software is based on 1000 data per query, as shown in Figure 1. The actual number of data retrieved from the Google Scholar web search at the moment this paper been written is 35,400 publications in total. This suggests that a revise searching strategy is required should researcher want to use Harzing's software to retrieve data from Google 
Scholar database. Perhaps performing a query based on a single year and compile the data of yearly based query may resolve this limitation.

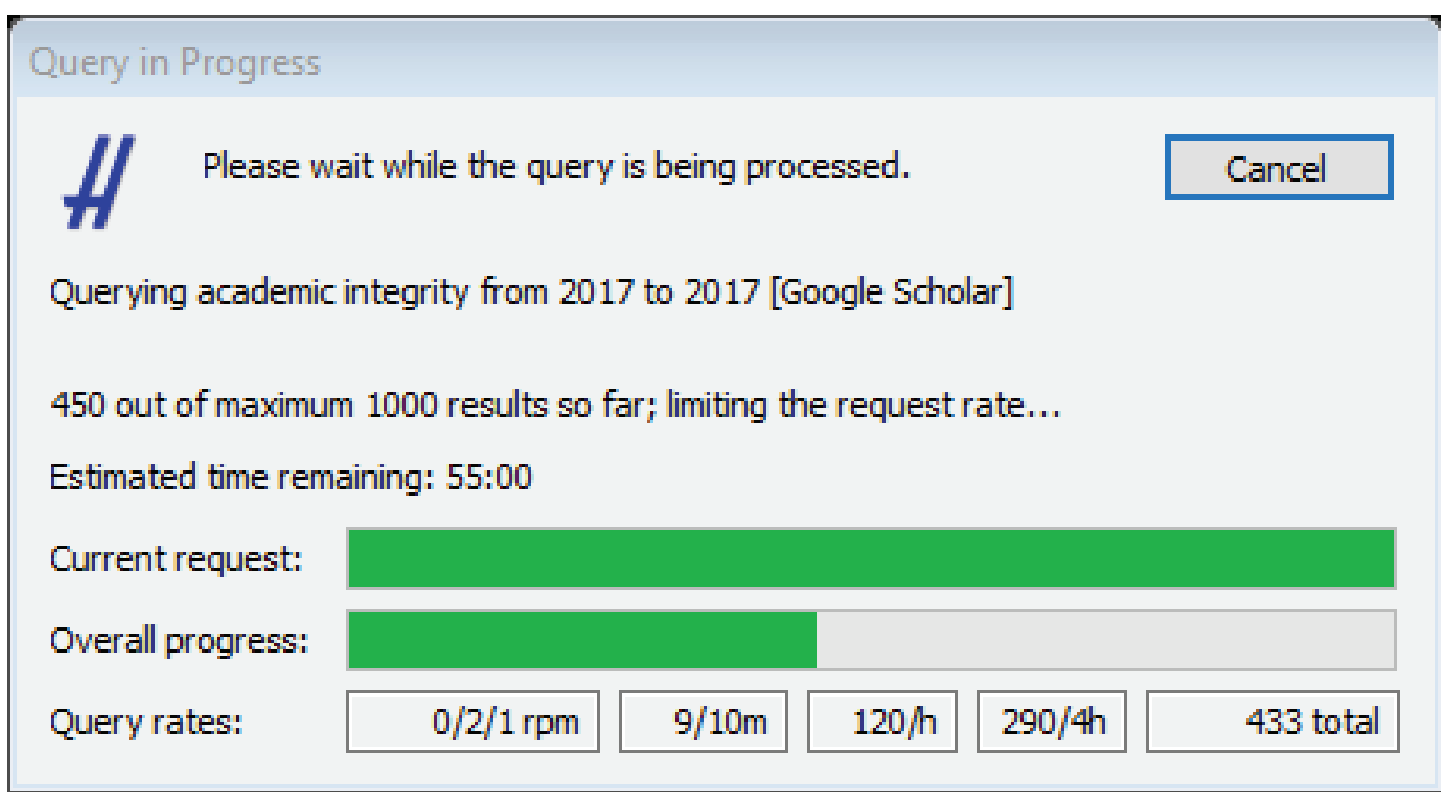

Figure 1: Limitation of Results in Harzing's Software.

b. The relationship between SCOPUS publication and Web referral has a positive correlation with Pearson's correlation coefficient value is 0.523 . Since the web is the most practical platform for higher education to engage with stakeholders(O'Haire et al., 2011), this relationship might provide researchers and practitioners two possible scenarios:-

i. Scenario 1: Research publication in "academic integrity" do affect web referral or citations.

ii. Scenario 2: Research publication in "academic integrity" is affected by web referral or citations.

iii. Scenario 3: Research publication in "academic integrity" is a two-way effect on web referral or citations.

c. The relationship between SCOPUS publication with social media is a very strong positive value where Pearson's correlation coefficient value is 0.915 . Although SCOPUS database is a subscription-based and usually access limited to subscribe researchers only, this finding indicates that the topic of "academic integrity" in published research works and social media has strong connection to each other.

2. RQ2: What is the impact of research publication on "academic integrity" in higher education in the form of research citation and web citation? 
a. A strong positive relationship between research publications and citation in the publications indexed in Google Scholar indicates that there is an impact of published works in "academic integrity" on the research citation and web citation. Table 6 summarizes the impact value of research on citation-based in Appendix 1.

TABLE 6: Research Impact of "Academic Integrity" on Research Citation and Web Citation.

Research Publication
Google Scholar
SCOPUS

\begin{tabular}{|c|c|}
\hline \multicolumn{2}{|c|}{ Research Citation } \\
\hline Google Scholar & SCOPUS \\
\hline 0.52 & 0.81 \\
\hline-0.54 & -0.15 \\
\hline
\end{tabular}

\begin{tabular}{|c|c|}
\hline \multicolumn{2}{|c|}{ Web Citation } \\
\hline Web Referral & Social Media \\
\hline-0.88 & -0.42 \\
\hline 0.52 & 0.92 \\
\hline
\end{tabular}

\section{Conclusion}

This study has investigated the relationship of research works on "academic integrity" with web citation. Findings supported that research impact of "academic integrity" can be assessed with web citation and social media sharing. Pearson's correlation coefficient value shows a strong relationship between research publication indexed by SCOPUS to social media sharing. This suggests that web citation can be used as a useful tool to measure the impact of research on academic integrity.

\section{Acknowledgement}

We would like to thank Yayasan Bank Rakyat for the financial support by sponsoring this paper to be presented in the FGIC $2^{\text {nd }}$ Conference on Governance and Integrity 2019. 


\section{Appendix 1: Correlation Matrix of "academic integrity" in publication and citation from 2009-2019}

\begin{tabular}{|c|c|c|c|c|c|c|c|c|c|}
\hline \multirow{2}{*}{\multicolumn{2}{|c|}{ Data Source }} & \multicolumn{4}{|c|}{ Publication } & \multicolumn{4}{|c|}{ Citation } \\
\hline & & $\begin{array}{l}\text { Google } \\
\text { Scholar }\end{array}$ & SCOPUS & $\begin{array}{l}\text { Google } \\
\text { Search }\end{array}$ & Web & $\begin{array}{c}\text { Google } \\
\text { Scholar }\end{array}$ & SCOPUS & Web Referral & Social Media \\
\hline \multirow{4}{*}{ 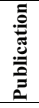 } & \begin{tabular}{|l|l|} 
Google Scholar \\
\end{tabular} & 1 & -0.32 & 0.38 & -0.80 & 0.52 & 0.81 & -0.88 & -0.42 \\
\hline & SCOPUS & & 1 & 0.51 & 0.610 & -0.54 & -0.15 & 0.52 & 0.92 \\
\hline & Google Search & & & 1 & 0.155 & -0.07 & 0.36 & 0.01 & 0.31 \\
\hline & Web & & & & 1 & -0.61 & -0.65 & 0.98 & 0.57 \\
\hline \multirow{4}{*}{ } & Google Scholar & & & & & 1 & 0.49 & -0.66 & -0.47 \\
\hline & SCOPUS & & & & & & 1 & -0.73 & -0.34 \\
\hline & Web Referral & & & & & & & 1 & 0.50 \\
\hline & Social Media & & & & & & & & 1 \\
\hline \multicolumn{10}{|c|}{ P-value from T-Test with two tails and paired } \\
\hline \multirow{4}{*}{ 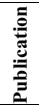 } & \begin{tabular}{|l} 
Google Scholar \\
\end{tabular} & & 0.230 & 0.000 & 0.018 & 0.011 & 0.000 & 0.004 & 0.045 \\
\hline & SCOPUS & & & 0.000 & 0.015 & 0.013 & 0.001 & 0.004 & 0.045 \\
\hline & Google Search & & & & 0.140 & 0.066 & 0.000 & 0.014 & 0.045 \\
\hline & Web & & & & & 0.061 & 0.309 & 0.003 & 0.045 \\
\hline \multirow{4}{*}{ 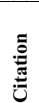 } & Google Scholar & & & & & & 0.019 & 0.381 & 0.046 \\
\hline & SCOPUS & & & & & & & 0.008 & 0.045 \\
\hline & Web Referral & & & & & & & & 0.046 \\
\hline & Social Media & & & & & & & & \\
\hline
\end{tabular}

\section{References}

[1] 'Alī, 'Abdullah Yūsuf. (1994). The meaning of Holy Qur'ān (5th ed.). Brentwood, Maryland: Amana Corp.

[2] Al-Bukhārī, M. B. I. A. 'Abdullāh al-J. (1987). Sahịh al-Bukhārī (3rd ed.). Beirūt: Dār lbn Kathīr.

[3] Altbach, P. G., \& Vest, C. M. (2005). Academic Corruption: The Continuing Challenge. International Higher Education, 38, 5-6.

[4] Amigud, A., Arnedo-Moreno, J., Daradoumis, T., \& Guerrero-Roldan, A. E. (2018). An integrative review of security and integrity strategies in an academic environment: Current understanding and emerging perspectives. Computers and Security, 76, 50-70. https://doi.org/10.1016/j.cose.2018.02.021

[5] Amigud, A., \& Lancaster, T. (2019). 246 reasons to cheat: An analysis of students' reasons for seeking to outsource academic work. Computers and Education. https: //doi.org/10.1016/j.compedu.2019.01.017

[6] Bouville, M. (2008). Plagiarism: Words and ideas. Science and Engineering Ethics, 14(3), 311-322. https://doi.org/10.1007/s11948-008-9057-6

[7] Council, C. N. R. (1991). Computers at Risk: Safe Computing in the Information Age (3rd ed.). Washington, D.C.: National Academy Press.

[8] DoJ, U.. A. O. (2019). Arrests Made in Nationwide College Admissions Scam: Alleged Exam Cheating \& Athletic Recruitment Scheme.

[9] Downes, M. (2017). University scandal, reputation and governance. International Journal for Educational Integrity. https://doi.org/10.1007/s40979-017-0019-0 
[10] Ercegovac, Z., \& Richardson, J. V. (2014). Academic Dishonesty, Plagiarism Included, in the Digital Age: A Literature Review. College \& Research Libraries. https://doi.org/ $10.5860 / \mathrm{crl} .65 .4 .301$

[11] Grolleau, G., Lakhal, T., \& Mzoughi, N. (2016). An Introduction to the Economics of Fake Degrees. Journal of Economic Issues. https://doi.org/10.1080/00213624.2008. 11507173

[12] Hayes, T. J., Ruschman, D., \& Walker, M. M. (2009). Social networking as an admission tool: A case study in success. Journal of Marketing for Higher Education, 19(2), 109124. https://doi.org/10.1080/08841240903423042

[13] Housewright, R., \& Schonfeld, R. (2008). Studies of Key Stakeholders in the Digital Transformation in Higher Education. Ithaka. https://doi.org/10.1080/ 08841240802100345

[14] Huberts, L. W. J. C. (2018). Integrity: What it is and Why it is Important. Public Integrity, 9922. https://doi.org/10.1080/10999922.2018.1477404

[15] Liu, Q., \& Peng, Y. (2015). Determinants of willingness to bribe: Micro evidence from the educational sector in China. Jahrbucher Fur Nationalokonomie Und Statistik.

[16] Mathews, J. A., \& Hu, M.-C. (2007). Enhancing the Role of Universities in Building National Innovative Capacity in Asia: The Case of Taiwan. World Development, 35(6), 1005-1020. https://doi.org/10.1016/j.worlddev.2006.05.012

[17] Maurer, H., Kappe, F., \& Zaka, B. (2006). Plagiarism - A Survey. Journal of Universal Computer Science, 12(8), 1050-1084.

[18] McCabe, D. L., Treviño, L. K., \& Butterfield, K. D. (2001). Cheating in academic institutions: A decade of research. Ethics and Behavior. https://doi.org/10.1207/ S15327019EB1103_2

[19] Mohd Hasrul Shuhari, U. of S. Z. A., Mohd Fauzi Hamat, U. of M., Mohammed Muneer'deen Olodo al-Shafi'i, U. of S. Z. A., Wan Hishamudin Wan Jusoh, U. of S. Z. A., Abidin, S. A. M. Z. U. of S. Z., \& Muhammad Rashidi Wahab, U. of S. Z. A. (2019). The Concept of Integrity for Muslim's Character Based on Al-Ghazali's Ethical Perspective. Journal of Legal, Ethical and Regulatory Issues (Print ISSN: 1544-0036; Online ISSN: 1544-0044), Vol: 22(1).

[20] Muslim, I. ḥajjāj A. al-ḥusain al-Q. al-N. (n.d.). Șaḥ̣ị̣ Muslim. Beirūt: Dār Ihyā' al-Turāthi al-'Arabī.

[21] Nurunnabi, M., \& Hossain, M. A. (2019). Data falsification and question on academic integrity. Accountability in Research. https://doi.org/10.1080/08989621. 2018.1564664 
[22] O’Haire, C., McPheeters, M., Nakamoto, E., LaBrant, L., Most, C., Lee, K., ... Guise, J.M. (2011). Engaging Stakeholders To Identify and Prioritize Future Research Needs. Methods Future Research Needs Reports, No. 4.

[23] OECD. (2018). Integrity of Education Systems: A Methodology for Sector Assessment.

[24] Quain, J. (1831). MR. QUAIN'S REPLY TO A CHARGE OF PLAGIARISM. The Lancet, 15(392), 757-758. https://doi.org/10.1016/S0140-6736(02)39623-5

[25] Rajnish Kumar, Pritam Desale, C. G. P. (2013). Web Based Admission System. International Journal of Emerging Technology and Advanced Engineering.

[26] Rogers, D. L. (2000). A Paradigm Shift: Technology Integration for Higher Education in the New Millennium. AACE Journal.

[27] Sharma, D. C. (2015). India's medical education system hit by scandals. The Lancet, 386(9993), 517-518. https://doi.org/10.1016/s0140-6736(15)61462-3

[28] Sibbel, A. (2009). Pathways towards sustainability through higher education. International Journal of Sustainability in Higher Education, 10(1), 68-82. https: //doi.org/10.1108/14676370910925262

[29] Sumi, R., \& Mesner-Andolšek, D. (2016). The integrity of the servant leader. The Integrity of the Servant Leader (1st ed.). Routledge. https://doi.org/10.4324/ 9781315449647

[30] Taatila, V. (2017). Paradigm shift in higher education? On the Horizon, 25(2), 103-108. https://doi.org/10.1108/OTH-06-2016-0030

[31] Tierney, W. G., \& Sabharwal, N. S. (2017). Academic corruption: Culture and trust in Indian higher education. International Journal of Educational Development, 55(March), 30-40. https://doi.org/10.1016/j.ijedudev.2017.05.003

[32] Walton, C. (2001). Character and Integrity in Organizations: The Civilization of the Workplace. Business and Professional Ethics Journal.

[33] Wang, X. H., \& Wan Wart, M. (2007). When public participation in administration leads to trust: An empirical assessment of managers' perceptions. Public Administration Review. https://doi.org/10.1111/j.1540-6210.2007.00712.x

[34] Weller, M., \& Anderson, T. (2013). Digital resilience in higher education. European Journal of Open, Distance and e-Learning.

[35] Zorn, A., Haywood, J., \& Glachant, J.-M. (2018). Higher Education in the Digital Age. Higher Education in the Digital Age. https://doi.org/10.4337/9781788970167 